\title{
Emerging Treatment Options of Regenerative Medicine in Severe Corona Virus/COVID 19 Infections
}

\author{
Ashok Kumar ${ }^{1,2}$, Sharda Brata Ghosh ${ }^{3}$ \\ ${ }^{I}$ Department of Orthopedics, My Doc Specialist Medical Centre DMCC, Dubai, UAE \\ ${ }^{2}$ Department of Orthopedics, Saudi German Hospital, Dubai, UAE \\ ${ }^{3} H O D$ of Department of Obs-Gynae, Saudi German Hospital, Dubai, UAE
}

COVID-19 pandemic has brought the whole world stand still, locked down in their homes, infecting more than 8 million people, and many thousands $(449,182)$-have lost their lives across the globe. Due to lack of any definitive medicine or vaccine, treatment options are supportive of oxygenation, antiviral, antiretroviral drugs, antibiotics, flu$\mathrm{id} /$ electrolyte, mechanical ventilation with ICU (Intensive Care Unit) support, and chloroquine/hydroxychloroquine have been tried to fight this infection. However, mortality due to severe pneumonia, ARDS (Acute Respiratory Distress Syndrome), and multiorgan failure arising from the overactive immune response (storm) mediated by cytokines remains a treatment challenge in elderly and patients with severe medical comorbidities. Recently, anti-inflammatory, angiogenic, immune-modular, and healing properties of intravenous injections of culture derived stem cells have been proposed and shown to benefits in a small number of patients with severe COVID-19 infections. Based on previous experience with other viral infections, convalescent plasma, and serum transfusion are being used as a source of neutralizing antibody/factors to minimize the effects of inflammatory cytokines in this infection. Immunotherapy with purified monoclonal antibodies and conditioned serum with a mixture of unique cytokines are also being developed. Regenerative Medicine has emerged as a crucial adjuvant tool in promoting healing and early recovery in severe COVID-19 infections and other supportive treatments.

Keywords: Regenerative medicine, Treatment options, Corona virus, COVID-19, Severe infections

\section{Introduction}

COVID-19 is caused by a newly found virus named as Severe Acute Respiratory Syndrome Coronavirus 2 (SARS-

Received: May 6, 2020, Revised: June 19, 2020,

Accepted: June 29, 2020, Published online: August 31, 2020

Correspondence to Ashok Kumar

Department of Orthopedics, Saudi German Hospital, Hessa Street, Al Barsha 3, Dubai 391093, UAE

Tel: +971-4-3890000, Fax: +971-4-3890032

E-mail: akkadamb2004@gmail.com

(a) This is an open-access article distributed under the terms of the Creative Commons Attribution Non-Commercial License (http://creativecommons.org/ licenses/by-nc/4.0/), which permits unrestricted non-commercial use, distribution, and reproduction in any medium, provided the original work is properly cited.

Copyright (c) 2020 by the Korean Society for Stem Cell Research
CoV-2) by Corona study group (1). Originally it was believed to be a zoonotic disease, and later it started infecting humans (2); now, its showing human to human transmission and has become pandemic involving more than 200 countries. The virus was initially believed to have transmission by close contact and air droplets $(2,3)$ then later it was found to have possible air transmission also $(4,5)$. Air transmission prompted regulatory authorities to impose involuntary social distancing, locked down at home, improving personal hygiene, and using masks and gloves while having symptoms or going out for medical treatment or emergencies.

\section{Etiopathogenesis of COVID 19 Infection}

COVID 19 virus enters the human cell binding (Fig. 1), 


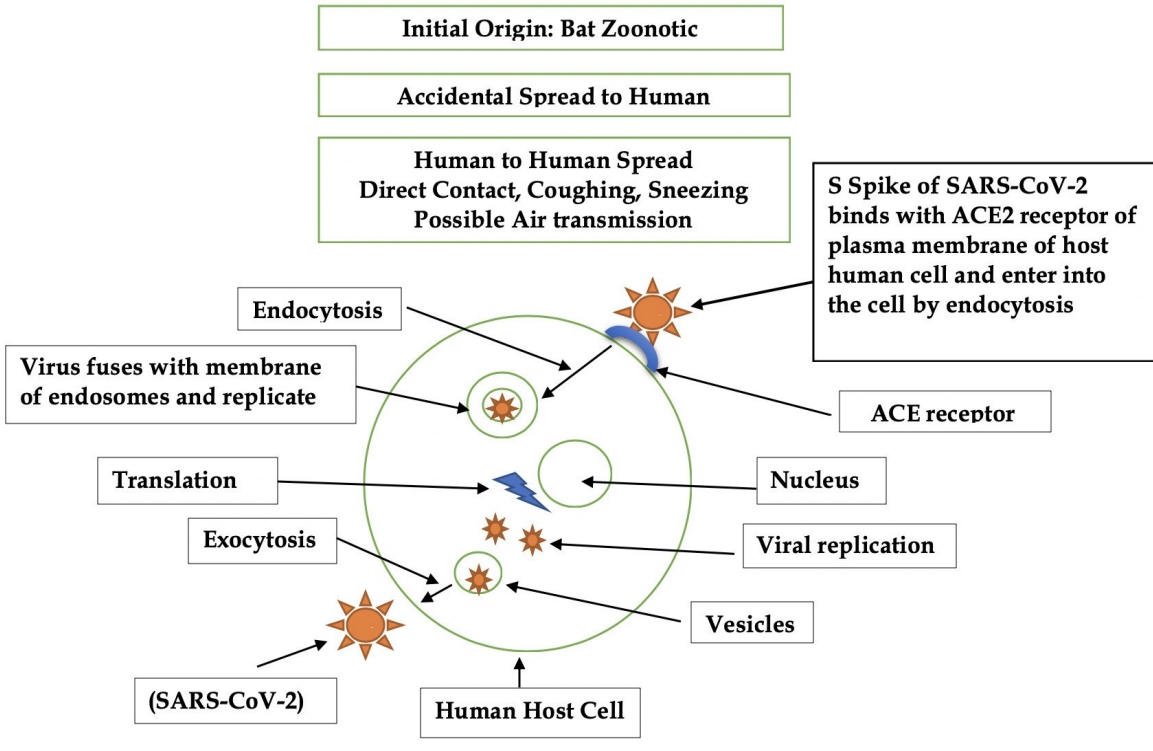

Fig. 1. Etiopathogenesis: Severe Respiratory Syndrome Coronavirus Infection (SARS-CoV-2)/COVID-19. through its S spike protein (6), to Angiotensin-Converting Enzyme 2 (ACE2) receptor (7) present on type 2 Alveoli cells, endothelial cells, heart, kidney, liver and other organs (8). The human body has been shown to have an overreactive immune response called cytokine storm (3) caused by increased level of interleukin (IL)-2, IL-6, IL-7, granulocyte colony-stimulating factor (GSCF), interferon $\gamma$-induced protein 10 (IP10), monocyte chemoattractant protein-1 (MCP1), macrophage inflammatory protein (MIP1A) and tumor necrosis factor-alpha (TNF- $\alpha$ ). Cytokine storm causes severe pneumonia by diffuse damage of type 2 alveolar, small blood vessels injury with capillary leakage into the air space causing pulmonary edema, pulmonary infarct, reduced oxygen exchange, and eventually acute respiratory distress syndrome (9). Many patients have been shown to have multiorgan failure involving the heart (myocarditis, thrombosis) (9), kidney, liver, and vascular system.

\section{Current Issues with Treatment Options of Severe COVID-19 Infection}

Around $80 \%$ of COVID-19 patients present with mild illness, $14 \%$ severe, and 5\% present with critical illness (10). Severe COVID-19 infection leads pneumonia, ARDS (Acute Respiratory Distress Syndrome), multiorgan failure is being seen in elderly and patients with significant medical comorbidities like chronic lung disease, diabetes, cardiac, hepatorenal diseases, and cancer patients (10). Currently, there are no validated COVID-19 specific antiviral drugs, vaccines, immunotherapy, or other treatment options. These patients are being managed by supportive treatment (Fig. 2) with oxygenation, antibiotics, fluid and electrolytes replacement, mechanical ventilation with ICU support to prevent complications like pneumonia, ARDS, organ failure, and death (11). Over the last few months, some other treatment options (Fig. 2) including antiviral drugs (remdesivir, Favipiravir), antiretroviral drugs (Lopinavir + Ritanovir), antibiotic (Azithromycin), antimalarial drugs (Chloroquine/Hydroxy Chloroquine: increases the $\mathrm{Ph}$ in the endosomes of cell and prevent virus-endosome fusion required for viral replication; interfere with terminal glycosylation of cellular receptor ACE 2 (Angiotensin Converting Enzyme 2) and reduces virus affinity binding to ACE receptor), immunosuppressant (Actemra, or tocilizumab and Sarilumab/approved cks (chemokine) IL-6 receptor for Rheumatoid Arthritis) and vaccines are being used with variable results in many countries (11-14). Now many actual reasons for death, including virus-induced severe tissue damage, overactive body immune response (cytokine storm) to the virus, mechanical ventilation-induced injuries, are being debated among the treating physician and research scientists. Drug regulatory authorities and governments are also feeling pressure to ease the use of the options mentioned earlier on compassionate grounds in COVID-19 infection and to conduct clinical trials to validate their efficacy in COVID-19 infections. 

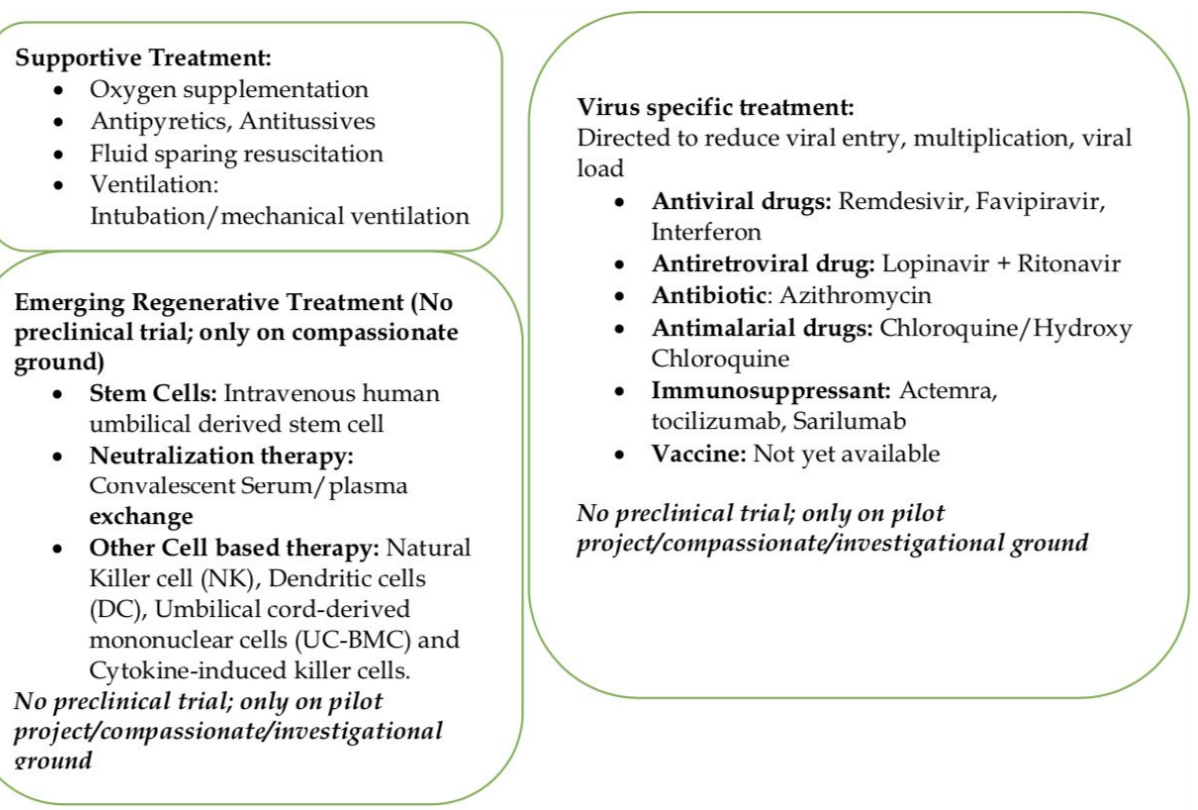

Fig. 2. Current treatment options for COVID-19/SARS-CoV-2 infections.

\section{Role of Regenerative Medicine in Severe COVID 19 Infections}

\section{Stem cells}

Mesenchymal stem cells have been shown to act by paracrine and juxtacrine signaling $(15,16)$ and to exhibit anti-inflammatory, anti-fibrotic (Fibroblast Growth Factor, Hepatic Growth Factor), angiogenic, mitogenic, antiapoptotic $(17,18)$ and immunoregulatory properties (prostaglandin GE2, TNF $\alpha$-stimulated gene-6, extracellular vesicles) (18-21). The majority of the intravenously injected stem cells get trapped in the lung veins and lung tissues. These trapped stem cells are resistant (immune) to Novel COVID-19 due to lack of surface ACE 2 receptor and TMRESS receptor on stem cells. Trapped stem cells release anti-inflammatory cytokines (22), angiogenic growth factor $(23,24)$, antimicrobial peptides $(23,25)$ extracellular vesicles $(24,25)$. These lung-specific anti-inflammatory mediators are released by stem cells activation through activation of Toll-Like Receptors (TLRs; pathogen-associated molecular pathogen receptors) present on stem cells by viral RNA (TLR3 also found in COVID-19) and viral unmethylated CpG-DNA (TLR9) (23, 26, 27). Angiopoietin-1 (Ang-1) and keratinocyte growth factor (KGF) help in the repair of alveolar-capillary barriers seen in $\operatorname{ARDS}(23,28)$. Those promote lung healing and repair by improving the pulmonary microenvironment (IL-10, VEGF), protecting alveolar epithelial cells, and preventing pulmonary fibrosis (29-32). Stem cells also seem to work against COVID 19 by elevating the level of MSC- specific
Interferon Stimulated Gene (ISG), which acts as a mediator of antiviral protection and by combined natural and inducible innate antiviral defense (23). Actions of stem cell at a pulmonary level are manifested in peripheral blood by a reduced level of inflammatory factors (pro-inflammatory cytokines: IFN- $\alpha$, IFN- $\gamma$, IL-1 $\beta$, IL-6, IL-12, IL-18, IL-33, TNF- $\alpha$, TGF $\beta$; chemokines: CCL 2, CCL3, CCL5, CXCL8, CXCL9, CXCL10) and increased level of anti-inflammatory factors and by suppressing immune cells (33). One recent study (34) reported the use allogeneic human umbilical cord-derived stem cells in a 65 years old female with COVID-19 infection on a noninvasive ventilator with severe pneumonia, ARDS, multiorgan failure, moderate anemia, hypertension, type 2 diabetes, electrolytes disturbance, immunosuppression and acute gastrointestinal bleeding (steroid side effect). The patient was not responding to steroid (methylprednisolone), antiviral drug (lopinavir/ritonavir, IFN- $\alpha$ inhalation) antibiotic (moxifloxacin) and immunosuppressant (Thymosin alpha). She had increased total leucocyte (TLC) and neutrophil count, decreased lymphocyte count, increased bilirubin and liver enzymes, and bilateral ground-glass opacity on C.T. (computer tomography) chest. The patient received three intravenous infusions of human umbilical cord-derived stem cells $\left(5 \times 10^{7}\right.$ hUCMSC) at three days apart; after second dosage her TLC/Neutrophil count reduced to a normal level, lymphocyte count increased to normal; serum bilirubin, CRP (C Reactive Protein), and ALT (Alaline Aminotransferase)/AST (Aspartate Aminotransferase) reduced gradually; the patient became ambu- 
latory on 4th day and was out of ICU on 13th day with improved C.T. lung findings. The authors acknowledged, single case experience might not be suitable to recommend stem cell therapy but did suggest either alone or in combination with other immune-modulating agents, stem cells could help severe COVID-19 infected patients.

Similar results were seen in a pilot project (33) looking at the role of single intravenous dose $\left(1 \times 10^{6}\right.$ cells $/ \mathrm{kg}$ body weight) of allogeneic human umbilical cord-derived stem cells in COVID-19 patients not responding well to expectant treatments. The study was conducted in Beijing YouAn Hospital, Capital Medical University, China after ethical approval from hospital and trial was reviewed by the scientific committee at International Society on Aging and Disease (ISOAD) and registered in the Chinese Clinical Trial Registry (ChiCTR2000029990). The study included seven COVID 19 infected patients (one critically severe, four severe, two common). Patients were assessed for 14 days for safety (allergic reaction, secondary infections, life-threatening events), primary efficacy (level of cytokines, CRP, oxygen saturation), secondary outcome (total lymphocyte count, fever, dyspnea, respiratory rate, C.T. chest) after the injection. The study showed improvement in symptoms and pulmonary function in 2 days, and three patients (one severe, two common infections) were discharged ten days after the treatment. Laboratory results showed a reduced level of C-reactive protein and TNF- $\alpha$ (Tumor Necrotic Factor), the disappearance of overactivated cytokine-secreting immune cells CXCR3+CD4+ $\mathrm{T}$ cells, CXCR3 $+\mathrm{CD} 8+\mathrm{T}$ cells, and CXCR (chemokine receptor) $3+$ Natural Killer cells (3 6 days); increased level of peripheral lymphocytes, CD14+CD11c+CD11b, regulatory D.C. cell \& IL-10 (stem cell group). They also performed the $10 \times$ RNA-seq survey on 12.500 captured MSCs (mesenchymal stem cell), and results showed MSCs are ACE2 or TMPRSS2 negative and expressed a high level of anti-inflammatory and trophic factors (Transforming Growth Factor - $\beta$, Hepatic Growth Factor, Leucocyte Inhibiting Factor, Fibroblast Growth Factor, Vascular Endothelial Growth Factor, Epidermal Growth Factor, Brain-Derived Neurotrophic Factor, and Nerve Growth Factor). They concluded that transplanted stem cells are safe, make immune to COVID-19 infection, and help in severe COVID-19 infections; although the main issue with the study is lack of detailed clinical information, levels of inflammatory cytokines, and lymphocytes in three patients treated by placebo and six non-critical patients in the stem cell group.

Nevertheless, these two reports of stem cells in COVID-19 patients do show the beneficial role of stem cells as an additional tool along with other treatments. More properly done randomized studies with long-term follow-up would help establish the treatment protocols (indications, timing, dosages, interval, route, type of stem cell, follow-up criteria, and safety) for stem cell treatment in these patients. Although both these studies have used human umbilical cord-derived stem cells, they avoided autologous harvesting-related complications and might have better clonogenic, proliferation, migration, and chondrogenic potential than bone marrow-derived mesenchymal stem cell (35, 36). However, they are allogenic and might have cultural/social issues; and most of the published literature is on the efficacy and safety of the bone marrow or adipose tissue-derived stem cells. Mesenchymal stem cells from bone marrow, adipose tissue, or umbilical cord should be able to show a similar effect in COVID-19 infections. These can be harvested (bone marrow, adipose tissue) at an early stage in patients with a high risk of developing the severe COVID-19; can be expanded in the lab (for 1 3 weeks) and used if the need arises at a later stage. Recently several clinical trials without any preclinical evidence have been registered in NIH and Chinese Clinical Trial sites for COVID-19 infections (23). These trials will be using MSC alone (systemic administration of human umbilical cord-derived, human menstrual blood-derived, adipose tissue-derived, Wharton Jelly derived stem cell), or in a combination of MSCs derived products (MSCs Exosomes by inhalation; Umbilical derived mononuclear cells conditioned medium; drugs like Ruxolitinib) or MSC derived exosomes (inhalation route) alone (23). A variable $1 \sim 5$ dosages of intravenous stem cell between 0.4 and $42 \times 10^{6}$ cells $/ \mathrm{kg}^{-1}$ at two days interval will be used for these trials (23).

\section{Other Cell-Based Therapies}

Now many trials are being proposed and will be started soon to see the efficacy and safety of other potential antiviral cells, including natural killer cells (N.K.), dendritic cells (D.C.), Umbilical cord-derived mononuclear cells (UC-BMC) and cytokine-induced killer cells (23). Recently, Cellularity, a clinical-stage company, has got FDA approval for Investigational New Drug (IND) application for the use of its registered CYNK-001 in adults with COVID19 (37). It is a cryopreserved allogenic Natural Killer Cell derived from a human placental hematopoietic stem cell. CYNK-001 has been proposed to activating receptors such as NKG2D, DNAM-1, and the natural cytotoxicity receptors NKp30, NKp44, and NKp46, which bind to stress ligands and viral antigens on infected cells (37). It has also 
been proposed to show the expression of cytolytic molecules perforin and granzyme $\mathrm{B}$, which kill recognized infected cells. Although these proposed actions of CYNK-001 have been suggested to help COVID-19 patients by reducing viral replication and eliminating the infected cells (37). However, there is uncertainty about the dosages, intervals, efficacy, and risk of increasing the severity by destroying the minimally infected cells or altering the other immune response against the COVID-19 virus.

\section{Convalescent Serum/Plasma}

Historically, they had been one of the commonly used methods of providing passive immunological protection by transfusing convalescent serum/plasma to prevent or treat an infectious disease (measles, chickenpox). They have also been used for Middle East Respiratory Syndrome Coronavirus in the past and recently for COVID-19 infection in China; now increasingly being used in other countries (USA, Italy, France), and FDA has also allowed it for COVID-19. They are collected from patients who were previously positive for the COVID-19 test, currently asymptomatic for 2 3 weeks, and are negative for the COVID-19 test. The patient's blood is collected and screened for other infections (Hepatitis B, C, HIV, Cytomegalovirus, Syphilis) and serum or plasma (titer of 1 : 160) is prepared; usual dosage ranges from one to multiple infusion of $200 \sim 400 \mathrm{ml}$ (ABO compatible) at few days' intervals. These are generally given as a rescue therapy $(38,39)$ at an early stage of infection (low viral load/inoculum) for immediate antiviral protection. They mainly work by neutralization of viruses from passive antibodies and possibly by antibody-dependent cellular cytotoxicity or phagocytosis $(38,40)$. Many benefits of these therapies have been proposed, including the reduced viral load, severity, and hospital duration of COVID-19 patients (38, $41,42)$. Now they are also being proposed for asymptomatic or mildly symptomatic COVID-19 positive healthcare professionals, as it gives immediate immunity, and they can reduce or avoid quarantine period and can continue to work in highly loaded hospitals. These treatments are generally have been safe \& effective, but doubt has raised about the quality and titer of antibodies present in these products; also, unknown risk of blood infection or unknown infection, and remote antibody-dependent lung injury or enhanced viral infection $(39,40,43)$. Plasma exchange has also been shown to reduce inflammatory cytokines, stabilizing endothelial membranes, and resetting the hypercoagulable state $(42,44,45)$. One study (41) used plasma exchange transfusion in 3 pediatric patients $(35 \sim$
$40 \mathrm{ml} / \mathrm{kg}$ ) on mechanical ventilation with acute ARDS \& hemodynamic instability during $2009 \mathrm{H} 1 \mathrm{N1}$ influenza. All the three patients benefited from anti-cytokine storm effects of plasma exchange and survived without any side effects. One randomized study (46) involving 106 patients with severe sepsis and shock; compared combined plasma exchange and standard care with standard treatment only, and showed a 28 days mortality rate of $33.3 \%$ in the plasma exchange group while $53.8 \%$ in the control group.

\section{Conclusions}

COVID 19 pandemic is threatening our existence and has changed human life forever due to the current unavailability of a particular medicine, vaccines, and other treatment options. Many efforts have been made to prevent viral entry, reduce viral load, and to control the COVID-19 induced tissue damage. However, mortality remains a big issue due to cytokine storm and inadequate healing potential in elderly and compromised unhealthy patients. Regenerative Medicine could become an essential adjuvant treatment in these severely affected patients by harnessing the anti-inflammatory, immune-modulatory, angiogenic and healing properties of stem cells and neutralizing actions of plasma/serum exchange and immunotherapy.

\section{Acknowledgments}

No financial grant was received for this paper.

\section{Potential Conflict of Interest}

The authors have no conflicting financial interest.

\section{Author Contributions}

Ashok Kumar \& Sharda Brata Ghosh collected data and wrote the manuscript.

\section{References}

1. Coronaviridae Study Group of the International Committee on Taxonomy of Viruses. The species Severe acute respiratory syndrome-related coronavirus: classifying 2019-nCoV and naming it SARS-CoV-2. Nat Microbiol 2020;5:536-544

2. Li Q, Guan X, Wu P, Wang X, Zhou L, Tong Y, Ren R, Leung KSM, Lau EHY, Wong JY, Xing X, Xiang N, Wu Y, Li C, Chen Q, Li D, Liu T, Zhao J, Liu M, Tu W, Chen C, Jin L, Yang R, Wang Q, Zhou S, Wang R, Liu H, Luo Y, Liu Y, Shao G, Li H, Tao Z, Yang Y, Deng Z, Liu B, Ma Z, Zhang Y, Shi G, Lam TTY, Wu JT, Gao GF, Cowling BJ, Yang B, Leung GM, Feng Z. Early transmission dynamics in Wuhan, China, of novel coronavi- 
rus-infected pneumonia. N Engl J Med 2020;382:1199-1207

3. Huang C, Wang Y, Li X, Ren L, Zhao J, Hu Y, Zhang L, Fan G, Xu J, Gu X, Cheng Z, Yu T, Xia J, Wei Y, Wu W, Xie X, Yin W, Li H, Liu M, Xiao Y, Gao H, Guo L, Xie J, Wang G, Jiang R, Gao Z, Jin Q, Wang J, Cao B. Clinical features of patients infected with 2019 novel coronavirus in Wuhan, China. Lancet 2020;395:497-506

4. Chan JF, Yuan S, Kok KH, To KK, Chu H, Yang J, Xing F, Liu J, Yip CC, Poon RW, Tsoi HW, Lo SK, Chan KH, Poon VK, Chan WM, Ip JD, Cai JP, Cheng VC, Chen H, Hui CK, Yuen KY. A familial cluster of pneumonia associated with the 2019 novel coronavirus indicating personto-person transmission: a study of a family cluster. Lancet 2020;395:514-523

5. Burke RM, Midgley CM, Dratch A, Fenstersheib M, Haupt T, Holshue M, Ghinai I, Jarashow MC, Lo J, McPherson TD, Rudman S, Scott S, Hall AJ, Fry AM, Rolfes MA. Active monitoring of persons exposed to patients with confirmed COVID-19- United States, January-February 2020. MMWR Morb Mortal Wkly Rep 2020;69:245-246

6. Chen Y, Guo Y, Pan Y, Zhao ZJ. Structure analysis of the receptor binding of 2019-nCoV. Biochem Biophys Res Commun 2020;525:135-140

7. Yan R, Zhang Y, Li Y, Xia L, Guo Y, Zhou Q. Structural basis for the recognition of SARS-CoV-2 by full-length human ACE2. Science 2020;367:1444-1448

8. Zou X, Chen K, Zou J, Han P, Hao J, Han Z. Single-cell RNA-seq data analysis on the receptor ACE2 expression reveals the potential risk of different human organs vulnerable to 2019-nCoV infection. Front Med 2020;14:185-192

9. Hanff TC, Harhay MO, Brown TS, Cohen JB, Mohareb AM. Is there an association between COVID-19 mortality and the renin-angiotensin system-a call for epidemiologic investigations. Clin Infect Dis 2020 doi:10.1093/cid/ciaa329. [Epub ahead of print]

10. People who are at increased risk for severe illness [Internet]. Atlanta: Centers for Disease Control and Prevention; 2020 Jun 25 [updated 2020 Jun 25; cited 2020 Jun 25]. Available from: https:/www.cdc.gov/coronavirus/2019-ncov/need-extraprecautions/people-at-increased-risk.html?CDC_AA_ref Val =https $\% 3 \mathrm{~A} \% 2 \mathrm{~F} \% 2 \mathrm{Fwww} . c d c . g o v \% 2 \mathrm{Fcoronavirus} \% 2 \mathrm{~F} 2$ 019-ncov\%2Fneed-extra-precautions\%2Fpeople-at-higherrisk.html.

11. World Health Organization. Clinical management of severe acute respiratory infection (SARI) when COVID-19 disease is suspected. Geneva: World Health Organization; 2020.

12. Gautret P, Lagier JC, Parola P, Hoang VT, Meddeb L, Mailhe M, Doudier B, Courjon J, Giordanengo V, Vieira VE, Dupont HT, Honoré S, Colson P, Chabrière E, La Scola B, Rolain JM, Brouqui P, Raoult D. Hydroxychloroquine and azithromycin as a treatment of COVID-19: results of an open-label non-randomized clinical trial. Int J Antimicrob Agents 2020 doi:10.1016/j.ijantimicag.2020.105 949. [Epub ahead of print]

13. Young BE, Ong SWX, Kalimuddin S, Low JG, Tan SY, Loh J, Ng OT, Marimuthu K, Ang LW, Mak TM, Lau SK,
Anderson DE, Chan KS, Tan TY, Ng TY, Cui L, Said Z, Kurupatham L, Chen MI, Chan M, Vasoo S, Wang LF, Tan BH, Lin RTP, Lee VJM, Leo YS, Lye DC. Epidemiologic features and clinical course of patients infected with SARS-CoV-2 in Singapore. JAMA 2020;323:1488-1494

14. Cao B, Wang Y, Wen D, Liu W, Wang J, Fan G, Ruan L, Song B, Cai Y, Wei M, Li X, Xia J, Chen N, Xiang J, Yu T, Bai T, Xie X, Zhang L, Li C, Yuan Y, Chen H, Li H, Huang H, Tu S, Gong F, Liu Y, Wei Y, Dong C, Zhou F, Gu X, Xu J, Liu Z, Zhang Y, Li H, Shang L, Wang K, Li K, Zhou X, Dong X, Qu Z, Lu S, Hu X, Ruan S, Luo S, Wu J, Peng L, Cheng F, Pan L, Zou J, Jia C, Wang J, Liu X, Wang S, Wu X, Ge Q, He J, Zhan H, Qiu F, Guo L, Huang C, Jaki T, Hayden FG, Horby PW, Zhang D, Wang C. A trial of lopinavir-ritonavir in adults hospitalized with severe Covid-19. N Engl J Med 2020;382:17871799

15. Gupta PK, Das AK, Chullikana A, Majumdar AS. Mesenchymal stem cells for cartilage repair in osteoarthritis. Stem Cell Res Ther 2012;3:25

16. Murphy JM, Fink DJ, Hunziker EB, Barry FP. Stem cell therapy in a caprine model of osteoarthritis. Arthritis Rheum 2003;48:3464-3474

17. Rehman J, Traktuev D, Li J, Merfeld-Clauss S, TemmGrove CJ, Bovenkerk JE, Pell CL, Johnstone BH, Considine RV, March KL. Secretion of angiogenic and antiapoptotic factors by human adipose stromal cells. Circulation 2004; 109:1292-1298

18. Block GJ, Ohkouchi S, Fung F, Frenkel J, Gregory C, Pochampally R, DiMattia G, Sullivan DE, Prockop DJ. Multipotent stromal cells are activated to reduce apoptosis in part by upregulation and secretion of stanniocalcin-1. Stem Cells 2009;27:670-681

19. Caplan AI. Why are MSCs therapeutic? New data: new insight. J Pathol 2009;217:318-324

20. Freitag J, Bates D, Boyd R, Shah K, Barnard A, Huguenin $\mathrm{L}$, Tenen A. Mesenchymal stem cell therapy in the treatment of osteoarthritis: reparative pathways, safety and efficacy- a review. BMC Musculoskelet Disord 2016;17:230

21. Harrell CR, Markovic BS, Fellabaum C, Arsenijevic A, Volarevic V. Mesenchymal stem cell-based therapy of osteoarthritis: current knowledge and future perspectives. Biomed Pharmacother 2019;109:2318-2326

22. Lee RH, Pulin AA, Seo MJ, Kota DJ, Ylostalo J, Larson BL, Semprun-Prieto L, Delafontaine P, Prockop DJ. Intravenous hMSCs improve myocardial infarction in mice because cells embolized in lung are activated to secrete the anti-inflammatory protein TSG-6. Cell Stem Cell 2009;5:54-63

23. Khoury M, Cuenca J, Cruz FF, Figueroa FE, Rocco PRM, Weiss DJ. Current status of cell-based therapies for respiratory virus infections: applicability to COVID-19. Eur Respir J 2020;55:2000858

24. Hu S, Park J, Liu A, Lee J, Zhang X, Hao Q, Lee JW. Mesenchymal stem cell microvesicles restore protein permeability across primary cultures of injured human lung microvascular endothelial cells. Stem Cells Transl Med 


\section{8;7:615-624}

25. Krasnodembskaya A, Song Y, Fang X, Gupta N, Serikov V, Lee JW, Matthay MA. Antibacterial effect of human mesenchymal stem cells is mediated in part from secretion of the antimicrobial peptide LL-37. Stem Cells 2010;28:2229-2238

26. Liotta F, Angeli R, Cosmi L, Filì L, Manuelli C, Frosali F, Mazzinghi B, Maggi L, Pasini A, Lisi V, Santarlasci V, Consoloni L, Angelotti ML, Romagnani P, Parronchi P, Krampera M, Maggi E, Romagnani S, Annunziato F. Toll-like receptors 3 and 4 are expressed by human bone marrow-derived mesenchymal stem cells and can inhibit their T-cell modulatory activity by impairing Notch signaling. Stem Cells 2008;26:279-289

27. Waterman RS, Tomchuck SL, Henkle SL, Betancourt AM. A new mesenchymal stem cell (MSC) paradigm: polarization into a pro-inflammatory MSC1 or an Immunosuppressive MSC2 phenotype. PLoS One 2010;5:e10088

28. Lee JW, Krasnodembskaya A, McKenna DH, Song Y, Abbott J, Matthay MA. Therapeutic effects of human mesenchymal stem cells in ex vivo human lungs injured with live bacteria. Am J Respir Crit Care Med 2013;187:751-760

29. Behnke J, Kremer S, Shahzad T, Chao CM, BöttcherFriebertshäuser E, Morty RE, Bellusci S, Ehrhardt H. MSC based therapies-new perspectives for the injured lung. J Clin Med 2020;9:682

30. Cruz FF, Rocco PRM. The potential of mesenchymal stem cell therapy for chronic lung disease. Expert Rev Respir Med 2020;14:31-39

31. Li D, Liu Q, Qi L, Dai X, Liu H, Wang Y. Low levels of TGF- $\beta 1$ enhance human umbilical cord-derived mesenchymal stem cell fibronectin production and extend survival time in a rat model of lipopolysaccharide-induced acute lung injury. Mol Med Rep 2016;14:1681-1692

32. Iyer SS, Co C, Rojas M. Mesenchymal stem cells and inflammatory lung diseases. Panminerva Med 2009;51:5-16

33. Leng Z, Zhu R, Hou W, Feng Y, Yang Y, Han Q, Shan G, Meng F, Du D, Wang S, Fan J, Wang W, Deng L, Shi H, Li H, Hu Z, Zhang F, Gao J, Liu H, Li X, Zhao Y, Yin K, He X, Gao Z, Wang Y, Yang B, Jin R, Stambler I, Lim LW, Su H, Moskalev A, Cano A, Chakrabarti S, Min KJ, Ellison-Hughes G, Caruso C, Jin K, Zhao RC. Transplantation of ACE2- mesenchymal stem cells improves the outcome of patients with COVID-19 pneumonia. Aging Dis 2020;11:216-228

34. Liang B, Chen J, Li T, Wu H, Yang W, Li Y, Li J, Yu C, Nie F, Ma Z, Yang M, Nie P, Gao Y, Qian C, Hu M. Clinical remission of a critically ill COVID-19 patient treated by human umbilical cord mesenchymal stem cells. ChinaXiv 2020 doi:10.12074/202002.00084

35. Bartolucci J, Verdugo FJ, González PL, Larrea RE, Abarzua E, Goset C, Rojo P, Palma I, Lamich R, Pedreros PA, Valdivia G, Lopez VM, Nazzal C, Alcayaga-Miranda F, Cuenca J, Brobeck MJ, Patel AN, Figueroa FE, Khoury $M$. Safety and efficacy of the intravenous infusion of umbilical cord mesenchymal stem cells in patients with heart failure: a phase $1 / 2$ randomized controlled trial (RIMECARD Trial [Randomized Clinical Trial of Intravenous Infusion Umbilical Cord Mesenchymal Stem Cells on Cardiopathy]). Circ Res 2017;121:1192-1204

36. González PL, Carvajal C, Cuenca J, Alcayaga-Miranda F, Figueroa FE, Bartolucci J, Salazar-Aravena L, Khoury M. Chorion mesenchymal stem cells show superior differentiation, immunosuppressive, and angiogenic potentials in comparison with haploidentical maternal placental cells. Stem Cells Transl Med 2015;4:1109-1121

37. Slater H. FDA accepts IND for NK cell therapy CYNK-001 to treat patients with COVID-19 [Internet]. Cranbury: Cancer Network; 2020 Apr 3 [cited 2020 Apr 3]. Available from: https://www.cancernetwork.com/view/fda-accepts-indnk-cell-therapy-cynk-001-treat-patients-covid-19.

38. Cheng Y, Wong R, Soo YO, Wong WS, Lee CK, Ng MH, Chan P, Wong KC, Leung CB, Cheng G. Use of convalescent plasma therapy in SARS patients in Hong Kong. Eur J Clin Microbiol Infect Dis 2005;24:44-46

39. Mora-Rillo M, Arsuaga M, Ramírez-Olivencia G, de la Calle F, Borobia AM, Sánchez-Seco P, Lago M, Figueira JC, Fernández-Puntero B, Viejo A, Negredo A, Nuñez C, Flores E, Carcas AJ, Jiménez-Yuste V, Lasala F, Garcíade-Lorenzo A, Arnalich F, Arribas JR; La Paz-Carlos III University Hospital Isolation Unit. Acute respiratory distress syndrome after convalescent plasma use: treatment of a patient with Ebola virus disease contracted in Madrid, Spain. Lancet Respir Med 2015;3:554-562

40. Benson AB, Moss M, Silliman CC. Transfusion-related acute lung injury (TRALI): a clinical review with emphasis on the critically ill. Br J Haematol 2009;147:431-443

41. Patel P, Nandwani V, Vanchiere J, Conrad SA, Scott LK. Use of therapeutic plasma exchange as a rescue therapy in 2009 pH1N1 influenza A--an associated respiratory failure and hemodynamic shock. Pediatr Crit Care Med 2011;12: e87-e89

42. Chang JC. Sepsis and septic shock: endothelial molecular pathogenesis associated with vascular microthrombotic disease. Thromb J 2019;17:10

43. Halstead SB. Dengue Antibody-Dependent Enhancement: Knowns and Unknowns. Microbiol Spectr. 2014 doi:10.1128/ microbiolspec.AID-0022-2014

44. Nguyen TC, Carcillo JA. Bench-to-bedside review: thrombocytopenia-associated multiple organ failure--a newly appreciated syndrome in the critically ill. Crit Care 2006;10:235

45. Knaup H, Stahl K, Schmidt BMW, Idowu TO, Busch M, Wiesner O, Welte T, Haller H, Kielstein JT, Hoeper MM, David S. Early therapeutic plasma exchange in septic shock: a prospective open-label nonrandomized pilot study focusing on safety, hemodynamics, vascular barrier function, and biologic markers. Crit Care 2018;22:285

46. Busund R, Koukline V, Utrobin U, Nedashkovsky E. Plasmapheresis in severe sepsis and septic shock: a prospective, randomised, controlled trial. Intensive Care Med 2002;28: $1434-1439$ 